\title{
PENGEMBANGAN ALAT BANTU LATIHAN SAMSAK BERBASIS TRAFFIC LIGHT TERHADAP KECEPATAN REAKSI TENDANGAN PADA ATLET TAEKWONDO
}

\author{
Adinda Rarasti ${ }^{1}$, Zulfan Heri ${ }^{2}$ \\ Fakultas Ilmu Keolahragaan, Universitas Negeri Medan \\ adindararasti@gmail.com,zulfan_heri67@yahoo.com
}

\begin{abstract}
Abstrak: Penelitian ini adalah bertujuan untuk mengembangkan alat bantu latihan samsak berbasis traffic light terhadap kecepatan reaksi tendangan pada atlet taekwondo tahun 2019. Subjek dalam penelitian ini adalah 15 orang atlet dojang sibayak, 15 orang atlet dojang UMA dan 15 orang atlet dojang ITM. Rancangan produk terlebih dahulu divalidasi oleh 3 orang ahli, 1 pelatih taekwondo, 1 ahli dibidang olahraga dan 1 ahli dibidang alat, dimana persentase validitasnya adalah 86,6\%-95\%. Hasil uji kelompok kecil melibatkan 10 orang atlet dojang Sibayak dan 10 orang atlet dojang ITM menunjukkan alat bantu latihan samsak berbasis traffic light dalam nyala lampu $L E D$, pengaturan Remote, dan dalam hal kegunaan, kesenangan serta kenyamanan alat dalam melakukan beberapa variasi tendangan 1, 2, 3 sudah memenuhi kriteria untuk dilanjutkan dalam uji coba kelompok besar karena persentase dari setiap model alat antara 80\%-100\%. Hasil uji kelompok besar terhadap 15 orang atlet dojang UMA dan 15 orang atlet dojang ITM dan 15 orang atlet dojang Sibayak menunjukkan bahwa alat bantu latihan samsak berbasis traffic light dalam nyala lampu $L E D$, pengaturan Remote, dan dalam hal kegunaan, kesenangan serta kenyamanan alat dalam melakukan beberapa variasi tendangan 1, 2, 3 sudah memenuhi kriteria untuk dilanjutkan dalam pembuatan produk massal karena persentase dari setiap model alat antara 88\%-100\%. Dapat disimpulkan bahwa alat bantu latihan samsak berbasis traffic light dapat meningkatkan kecepatan reaksi tendangan atlet dalam melakukan tendangan pada olahraga taekwondo.
\end{abstract}

Kata Kunci : Pengembangan,Traffic Light, Kecepatan Reaksi

\begin{abstract}
This study aims to develop a traffic light-based samsak training tool for the speed of kick reactions in taekwondo athletes in 2019. The subjects in this study were 15 well-trained athletes, 15 UMA dojang athletes and 15 ITM dojang athletes. The form that was made before was validated by 3 experts, 1 taekwondo trainer, 1 expert in the field of sports and 1 expert in the field of equipment, where the percentage of validity was $86.6 \%-95 \%$. Small group test results involving 10 Sibayak dojang athletes and 10 ITM dojang athletes showed traffic light-based samsak training aids in LED lights, Remote settings, and in terms of usability, pleasure and convenience of tools in doing a number of kick variations 1, 2, 3 already fulfills the criteria to be continued in a large group trial because the percentage of each tool model is between $80 \%-100 \%$. The results of a large group test on 15 UMA dojang athletes and 15 ITM dojang athletes and 15 Sibayak dojang athletes showed that traffic light-based samsak training aids in LED lights, Remote settings, and in terms of usability, pleasure and convenience in performing some variations of kicks 1, 2, 3 have met the criteria to be continued in making mass products because the percentage of each model of the tool is between $88 \%-100 \%$. It can be concluded that traffic light-based samsak training aids can increase the reaction speed of an athlete's kick in a kick in taekwondo.
\end{abstract}

Keywords: Development, Traffic Light, Reaction Speed

\section{PENDAHULUAN}

Taekwondo adalah olahraga beladiri moderen yang berakar pada beladiri tradisional Korea. Taekwondo terdiri dari tiga kata dasar, yaitu: Tae berarti kaki untuk menghancurkan dengan teknik tendangan, Kwon berarti tangan untuk menghantam dan mempertahankan diri dengan teknik tangan, serta Do yang berarti seni atau cara mendisiplinkan diri. Maka jika diartikan secara sederhana, Taekwondo berarti seni atau cara mendisiplinkan diri atau seni 
bela diri yang menggunakan teknik kaki dan tangan kosong (Yoyok,2003:6) . Taekwondo salah satu cabang olahraga bela diri yang dapat membentuk kesehatan fisik dan mental dalam olahraga bela diri taekwondo, disamping itu olahraga bela diri taekwondo adalah olahraga prestasi yang dipertandingkan baik di area regional maupun internasional. Dalam bela diri taekwondo yang sering dipertandingkan adalah kategori poomsae dan kyorugi.

Taekwondo sendiri adalah beladiri yang menggunakan serangan dengan kaki, di mana sasaran dalam tendangan taekwondo adalah kearah badan dan kepala. Tendangan dalam taekwondo terdiri berbagai macam tendangan. Setiap teknik tendangan memerlukan kekuatan dan kecepatan dalam melakukannya. Hal ini sesuai pendapat (Yoyok,2003:35) yaitu "untuk melakukan tendangan diperlukan kecepatan, kekuatan, dan terutama keseimbangan yang prima".

Salah satu factor pendukung dalam meningkatkan kecepatan reaksi dalam melakukan tendangan dengan megembangkan alat latihan. Alat yang dimaksud disini adalah alat yang bias membantu meningkatkan kemampuan kecepatan reaksi atlet pada saat melakukan tendangan dalam taekwondo.

Peneliti melakukan observasi di Dojang ITM, Dojang UMA, dan Dojang Sibayak. Hasil observasi diperoleh ada beberapa latihan yang dilakukan oleh atlet dimulai dari latihan fisik, kyorugi dan yang paling utama adalah latihan tendangan, latihan tendangan yang mereka lakukan dengan cara berpasangan dengan menggunakan target pyongyo yang dipegang oleh salah satu pasangan, selain menggunakan target pyongyo ada yang menggunakan samsak.

Samsak yang dimaksud masih secara manual dengan masih menggunakan orang lain untuk melakukannya ketika melakukan tendangan ada beberapa atlet yang sudah benar secara teknik dalam melakukan tendangan, hanya saja untuk kecepatan reaksinya masih kurang untuk mencapai hasil pertandingan yang maksimal dan dari hasil observasi di dojang tersebut belum ada yang menggunakan alat bantu latihan samsak untuk melatih kecepatan reaksi tendangan, alat yang digunakan di dojang tersebut untuk melatih kecepatan reaksi tendangan masih menggunakan alat yang pada umumnya saja yaitu seperti cone, peluit dan pyongyo.

Peneliti ingin mengembangkan alat yang bisa digunakan sebagai latihan kecepatan reaksi tendangan sehingga bisa menyelesaikan permasalahan-permasalahan yang muncul dalam beladiri taekwondo khusus untuk nomor kyorugi sehingga dapat melakukan tendangan dengan cepat dan tepat.

\section{Hakikat Kecepatan Reaksi}

Upaya pencapaian prestasi atau hasil optimal dalam berolahraga, memerlukan beberapa macam penerapan unsur pendukung keberhasilan seperti kecepatan. Kecepatan adalah waktu yang dibutuhkan oleh tubuh untuk melakukan suatu kerja fisik tertentu. Kecepatan dalam banyak cabang olahraga merupakan inti dan sangat diperlukan agar dapat dengan segera memindahkan tubuh atau menggerakkan anggota tubuh dari satu posisi ke posisi lainnya.

Menurut Harsono, (1988: 216), kecepatan adalah kemampuan untuk melakukan gerakan-gerakan yang sejenis secara berturut-turut dalam waktu sesingkatsingkatnya atau kemampuan untuk menempuh suatu jarak dalam waktu yang cepat. Selanjutnya menurut Syafrudin (2011: 87), kecepatan diartikan sebagai kemampuan untuk melakukan gerakan-gerakan dalam satu-satuan waktu tertentu yang ditentukan oleh fleksibilitas tubuh, proses sistem persarafan dan kemampuan otot. Menurut Imran (2013:129), kecepatan diartikan jenis aktivitas yang dilakukan dalam waktu yang sesingkat mungkin, yang peningkatannya adalah subjek dari semua faktor yang mempengaruhi, terutama aspek teknik dan faktor psikologi.

Berdasarkan pada beberapa pengertian tentang kecepatan yang disampaikan oleh para ahli tersebut di atas, maka dapat disimpulkan bahwa kecepatan merupakan suatu komponen kondisi fisik yang dibutuhkan untuk melakukan gerakan secara berturut-turut atau memindahkan tubuh dari posisi tertentu ke posisi yang lain pada jarak tertentu pada waktu yang sesingkat-singkatnya.

\section{Pengertian Reaksi}

Menurut Widiarti dalam Monalisa (2011: 3), reaksi (reaction) adalah kemampuan seseorang untuk melakukan atau bertindak secepatnya dalam menanggapi rangsangan yang ditimbulkan lewat indera (gerak penerima oleh suatu rangsang yang datang). Menurut Sutrisno dalam T Manoppo (2014: 15) reaksi adalah kemampuan seseorang untuk menjawab rangsangan secepat mungkin dalam mencapai hasil yang sebaik-baiknya.

Reaksi adalah kemampuan gerak yang ada pada manusia dalam melakukan aktifitas fisik dan ini merupakan wujud dari kemampuan organ-organ tubuh memenuhi kebutuhan dan menggunakan oksigen sehingga memungkinkan melakukan aktivitas fisik terus menerus tanpa istirahat, serta kemampuan membuang dan menghambat bertambahnya konsentrasi asam laktat di dalam tubuh. Komponen reaksi adalah rangsangan dan gerak, ketika seseorang menanggapi suatu rangsangan melalui indera tertentu, berarti orang tersebut telah melakukan reaksi, hanya saja kecepatan reaksi setiap orang berbeda-beda. 
Dari pendapat tersebut tentang kecepatan dan reaksi, maka dapat disimpulkan bahwa kecepatan reaksi adalah kemampuan individu untuk melakukan gerakan berulang saat menanggapi rangsangan dalam waktu yang sesingkat-singkatnya.

\section{Hakikat Traffic Light}

Traffic light merupakan bahasa yang berasal dari inggris, Traffic dapat diartikan kedalam bahasa Indonesia sebagai lalu lintas dan light diartikan sebagai lampu. Menurut Repository USU (dalam Binggeli 2003) lampu minyak dari batu adalah lampu pertama buatan manusia yang di buat oleh suku Cro Magnon 50.000 tahun yang lalu. Pencahayaan buatan terus berevolusi hingga Thomas Alva Edison menemukan lampu pijar pertama pada tahun 1879 yang berusia hanya 15 jam.

Traffic light yang dimaksud disini merupakan sebuah alat yang secara model nya hampir sama dengan lampu lalu lintas pada umumnya hanya saja jika Traffic light pada umumnya digunakan untuk rambu - rambu lalu lintas berbeda dengan Traffic light kali ini. Traffic light ini digunakan sebagai alat bantu latihan kecepatan reaksi tendangan yang mempunyai 3 lampu yaitu merah, kuning, hijau. Lampu yang digunakan disini merupakan lampu $L E D$, Menurut repository USU (dalam Manurung 2009) Sumber cahaya yang beredar di pasaran dibagi menjadi empat kelompok yaitu: Incandescent lamp (lampu pijar), Fluorescent lamp, Hight Intensity Discharge, dan Lampu LED.

Traffic light ini dibantu dengan Remote RF yang mempunyai 4 tombol yang fungsi nya untuk mengatur lampu mana saja yang ingin dihidupkan. Selain itu Traffic light ini dapat diatur waktunya sesuai keinginan. Adapun komponen yang digunakan dalam pembuatan traffic light ini sebagai berikut: Remote Rf (1), Relay (3), Lampu LED Strip (3), Potensiometer (1), dan Frame.

\section{Hakikat Samsak}

Samsak adalah alat bantu dalam olahraga beladiri sebagai media sasaran serangan untuk melatih tendangan dan pukulan. Pada awal penggunaannya, samsak hanya digunakan dalam berlatih pukulan cabang olahraga tinju, namun seiring berkembangnya jaman samsak dikembangkan untuk melatih tendangan dan variasi teknik lainya sehingga dapat dimanfaatkan dalam latihan cabang olahraga lainnya seperti taekwondo, karate, atau muaythai (Susan
Presley, Demand Media: Punching bags and safety.healthyliving.azcentral.com).

Konstruksi samsak harus dirancang dengan kokoh, karena media ini akan menjadi sarana sasaran pukulan dan tendangan atlet berulang kali. Menurut Nur Rifqi (dalam Mary M, 2002: 2) pada umumnya samsak berupa karung dari bahan kulit atau bahan sintetis seperti vinil berbentuk silinder yang diisi dengan bijibijian, pasir, kain, dan bahan lainnya.

Fungsi samsak secara umum adalah melatih power pukulan dan tendangan pada cabang olahraga beladiri. Menurut Nur Rifqi (dalam Mary M, 2002: 2) Samsak merupakan salah satu media latihan atlet untuk melatih kekuatan tendangan dan pukulan. Selain itu, pada perkembangannya samsak digunakan untuk melatih kelincahan, daya tahan, dan reaksi.

\section{METODE}

Metode yang digunakan pada penelitian ini adalah penelitian pengembangan yang mencakup mengembangankan produk, menguji keefektifan produk untuk mencapai tujuan yang diinginkan. Hasil akhir dari kegiatan penelitian dan pengembangan ini adalah alat bantu latihan samsak berbasis traffic light dalam olahraga taekwondo dilengkapi dengan spesifikasi produknya, sehingga dapat digunakan dalam membuat program latihan dalam meningkatkan kemampuan kecepatan rekasi tendangan pada olahraga taekwondo.

Tempat penelitian untuk kelompok kecil dilaksanakan di dojang Sibayak dan dojang ITM. Tempat penelitian kelompok besar dilaksanakan di dojang Sibayak dojang UMA, dan dojang ITM. Waktu penelitian dilakukan pada bulan April hingga Mei tahun 2019.

Sasaran penelitian atau pengguna yang menjadi sasaran dalam penelitian pengembangan alat bantu latihan samsak berbasis traffic light dalam taekwondo adalah seluruh masyarakat taekwondo. Bagi para pelatih bela diri taekwondo dapat menjadikan alat bantu latihan samsak berbasis traffic light sebagai variasi dalam melatih keceptan reaksi, sementara bagi atlet dapat meningkatkan kemampuan teknik tendangan dengan alat bantu latuhan samsak berbasis traffic light.

Adapun rancangan langkah-langkah pengembangan alat bantu latihan samsak berbasis traffic light terhadap kecepatan reaksi tendangan pada atlet taekwondo dalam penelitian ini sebagai berikut:

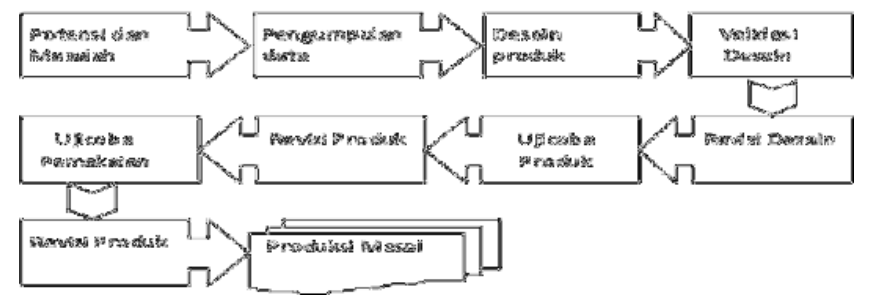

Gambar 1. Langkah-Langkah Penelitian 


\section{HASIL DAN PEMBAHASAN}

Analisis kebutuhan yang telah dilakukan terhadap 20 atlet taekwondo dari dojang Sibayak, dojang ITM dan dojang UMA diperoleh informasi bahwa $90 \%$ pelatih pernah memberikan latihan kecepatan reaksi, $30 \%$ atlet menyatakan bahwa pelatih pernah menggunakn alat dalam melatih kecepatan reaksi, 95,5\% atlet membutuhkan alat bantu latihan samsak untuk berlatih kecepatan reaksi tendangan, 95,5\% membutuhkan alat bantu latihan samsak yang berbasis traffic light dalam berlatih kecepatan reaksi tendangan, $100 \%$ altet menyatakan bahwa alat bantu latihan samsak yang berbasis traffic light dapat meningkatkan kemampuan dalam melakukan tendangan, 95,5\% atlet menyatakan bahwa alat bantu latihan samsak yang berbasis traffic light sesuai dengan kebutuhan untuk latihan tendangan.

Dari analisis kebutuhan yang dilakukan, dapat disimpulkan bahwa ide dari penelitian pengembangan ini adalah sangat perlu adanya pengembangan alat bantu latihan samsak berbasis traffic light untuk melatih kecepatan reaksi tendangan dalam olahraga taekwondo karena latihan tendangan dalam taekwondo yg sering digunakan hanya memakai samsak biasa yang masih memerlukan bantuan orang lain untuk dipegang.

Desain awal ataupun rancangan model alat ini telah diamati, dikoreksi dan dinyatakan layak untuk diuji cobakan oleh para ahli. Dalam pembuatan produk yang dikembangkan peneliti, peneliti berkonsultasi pada beberapa orang ahli dibidangnya dan memiliki keterkaitan dengan produk yang peneliti rancang yaitu 1 orang ahli pelatih, 1 orang ahli olahraga dan 1 orang ahli alat/media untuk menghasilkan produk yang sempurna. Evaluasi dilakukan untuk memperbaiki dan menyempurnakan alat bantu latihan sasaran yang telah dibuat.

Hasil uji coba kelompok kecil pada atlet dimana setelah melakukan latihan tendangan para atlet diberikan angket untuk diisi sesuai pemahaman atlet sendiri. Dari hasil uji coba kelompok kecil terhadap 20 orang atlet diketahui bahwa alat bantu latihan samsak berbasis traffic light dalam nyala lampu $L E D$, pengaturan Remote, dan dalam hal kegunaan, kesenangan serta kenyamanan alat dalam melakukan beberapa variasi tendangan 1, 2, 3 sudah memenuhi kriteria untuk dilanjutkan dalam uji coba kelompok besar karena persentase dari setiap model alat antara $80 \%-100 \%$.

Hasil uji coba kelompok besar terhadap 45 orang atlet diperoleh bahwa alat bantu latihan samsak berbasis traffic light dalam nyala lampu $L E D$, pengaturan Remote, dan dalam hal kegunaan, kesenangan serta kenyamanan alat dalam melakukan beberapa variasi tendangan 1, 2, 3 sudah memenuhi kriteria untuk dilanjutkan dalam pembuatan produk massal karena persentase dari setiap model alat antara 88\%-100\%. Dapat disimpulkan bahwa alat bantu latihan samsak berbasis traffic light dapat meningkatkan kecepatan reaksi tendangan atlet dalam melakukan tendangan pada olahraga beladiri taekwondo. Adapun penilaian dari ahli yang dilibatkan dapat digambarkan sebagai berikut.

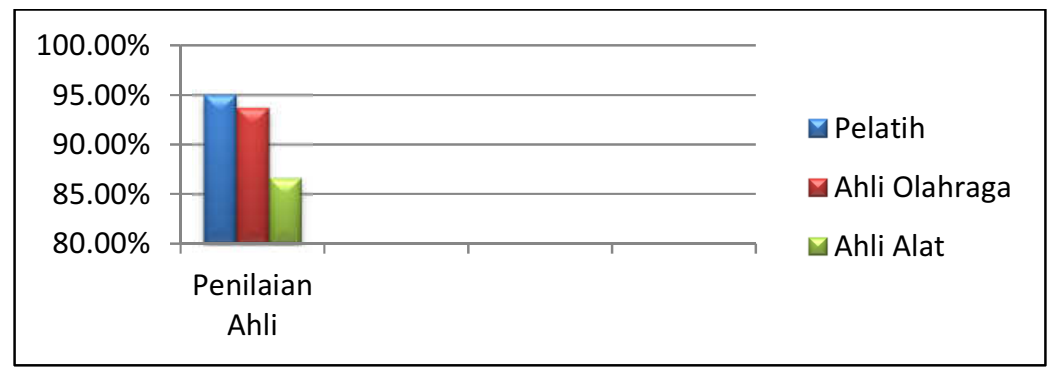

Gambar 2. Diagram Rata-Rata Penilaian Ahli

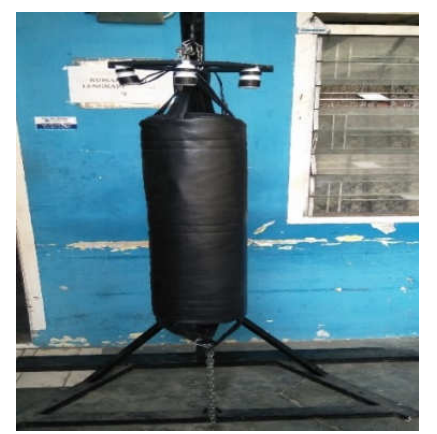

Gambar 3. Alat Bantu Latihan Samsak Berbasis Traffic Light 
Pengembangan produk ini bertujuan untuk meningkatkan kecepatan reaksi tendangan dalam taekwondo. Alat latihan reaksi tendangan ini sangat membantu atlet pada saat latihan tendangan. Alat bantu latihan samsak berbasis traffic light ini bisa digunakan kepada atlet yang sudah bisa melakukan tendangan dollyo chagi, deol $O$ chagi dan narae chagi sehingga atlet tinggal mengasah kecepatan reaksi tendangan agar tendangan lebih sempurna dan termasuk pada kriteria poin saat bertanding.

Alat ini menggunakan lampu Led Strip $12 \mathrm{~V} \mathrm{Dc}$ yang mana setiap satu mata lampu menggunakan $0.24 \mathrm{~W}$ dan arus listrik yang digunakan maksimum 14.4 W warna yang digunakan pada alat ini yaitu merah kuning dan hijau karena acuan pada kata traffic light yang pada umumnya menggunakan 3 warna lampu tersebut. Alat ini dapat membantu meningkatkan kecepatan reaksi karena alat ini di desain dengan menggunakan 3 lampu yaitu merah kuning dan hijau, dengan cara pengunaan nya pada saat salah satu lampu tersebut menyala maka atlet harus berpindah secepatnya ke lampu yang menyala tersebut dan melakukan tendangan yang sudah ditentukan, alat ini juga bisa diatur kecepatan perpindahan waktu lampunya sesuai dengan kebutuhan atlet, maka dari itu alat ini diharapkan dapat membantu kecepatan reaksi.

Alat bantu latihan samsak berbasis traffic light bisa digunakan pada atlet dengan tinggi badan yang beragam karena alat ini bisa diatur posisi tinggi dan rendahnya dengan tinggi minimum $155 \mathrm{~cm}$ dan tinggi maksimum $190 \mathrm{~cm}$ dan memiliki samsak dengan berat $6,2 \mathrm{~kg}$ Serta diameter lingkaran pada tiang adalah $30 \mathrm{~cm}$. Pada latihan yang digunakan pada alat bantu latihan samsak berbasis traffic light ialah alat tersebuat bisa di variasi kan, terdapat 3 tendangan yang dilakukan yaitu tendangan dollyo chagi, deol $O$ chagi dan narae chagi.

Berdasarkan pembahasan pengembangan alat bantu latihan samsak berbasis traffic light dalam melatih kecepatan reaksi memiliki keunggulan yaitu: Atlet lebih termotivasi dalam melaksanakan program latihan karena adanya variasi latihan dengan menggunakan alat, atlet lebih termotivasi untuk melakukan tendangan Dollyo Chagi, Deol O Chagi dan narae Chagi pada saat pertandingan, atlet mendapatkan pengalaman latihan yang lebih banyak sehingga memungkinkan membantu pada saat bertanding, proses dalam latihan tidak lagi monoton, mempermudah pelatih untuk menciptakan latihan yang lebih bervariasi.

\section{KESIMPULAN}

Berdasarkan pada data yang diperoleh dari hasil uji coba lapangan serta pembahasan hasil penelitian, maka dapat diambil kesimpulan bahwa alat bantu latihan samsak berbasis traffic light sudah layak untuk latihan kecepatan reaksi tendangan Dollyo Chagi, Deol O Chagi dan Narae Chagi. Hal ini dapat dilihat dari hasil penilaian atlet melalui angket ratarata $80 \%-100 \%$. Dengan adanya alat bantu latihan samsak berbasis traffic light ini dapat membantu pelatih dalam menjalankan program latihan serta dengan adanya alat bantu latihan samsak berbasis traffic light ini dapat melatih atlet dalam kecepatan reaksi tendangan dengan sajian latihan yang lebih efektif dan efesien serta tampilan latihan yang berbeda membuat atlet lebih termotivasi dan semangat.

\section{REFERENSI}

Harsono. 1996. Coaching Dan Aspek-Aspek Psikologis Dalam Coaching. Jakarta: CV.Kesuma

Imran. 2013. Dasar - dasar Melatih Fisik Olahragawan. Medan: Unimed Press

Nur, Rifqi. 2016. Pengembangan Samsak Elektrik Berbasis Flip Flop Acak Cabang Olahraga Beladiri. Skripsi. Yogyakarta: UNY

Sugiyono. 2015. Metode Penelitian (kuantitatif, kualitatif, dan $R \& D)$ Bandung: Alfabeta

Syafruddin. 2011. Ilmu Kepelatihan Olahraga. Padang: UNP Press Padang

Yoyok. 2003. Taekwondo Poomse Tae Geuk. Jakarta: PT. Gramedia Pustaka Utama 